\title{
Peningkatan Kapasitas Takmir Masjid Ibrahim di Kadipiro Yogyakarta dalam Pengelolaan Dana Infaq di Masa Pandemi Covid-19
}

\author{
Munjiati Munawaroh \\ Program Studi Ilmu Manajemen, Fakultas Ekonomi dan Bisnis, Universitas Muhammadiyah Yogyakarta \\ Lilis Setiartiti \\ Program Studi Ekonomi Pembangunan, Fakultas Ekonomi dan Bisnis, Universitas Muhammadiyah Yogyakarta \\ munjiatim@umy.ac.id \\ DOI: $10.18196 / p p m .31 .61$
}

\begin{abstract}
.
Permasalahan yang ditemukan di Masjid IbrahimKadipiro, Kelurahan Ngestiharjo, Kecamatan Kasihan, Kabupaten Bantul Yogyakarta adalah dalam hal pengelolaan dana infaq masjid yang belum optimal. Masih banyak dana yang belum teralokasi dengan baik. Program Kemitraan Masyarakat ini dilakukan untuk memberikan solusi dengan meningkatkan kapasitas takmir masjid dalam pengelolaan dana infaq Masjid Ibrahimuntuk kemaslahatan umat pada umumnya dan masyarakat sekitarnya. Kontribusi Program Kemitraan Masyarakat ini adalah membantu memperbaiki manajemen keuangan masjid dalam pemanfaatan dana infaq sehingga memberikan manfaat langsung terhadap kehidupan masyarakat terutama di ekonomi, pendidikan dan bidang sosial. Pengelolaan dana Infaq pada masa pandemi Covid-19 diprioritaskan untuk penanganan pandemi Covid-19, yaitu untuk pembagian sembako kepada masyarakat miskin yang terdampak pandemi Covid-19, penyemprotan disinfektan berkala ke masyarakat.

Kata kunci: infaq, masjid, Covid-19, kemaslahatan
\end{abstract}

\section{Latar Belakang}

Masjid memiliki fungsi utama sebagai tempat peribadatan sekaligus memiliki fungsi sosial bagi masyarakat. Peran masjid sebagai peribadatan sudah lazim diketahui oleh masyarakat luas, namun peran sebagai fungsi sosial masih belum banyak diterapkan oleh sebagian masyarakat, terutama oleh takmir masjid. Padahal, masjid memiliki dana yang bersumber dari infaq yang diberikan oleh masyarakat. Salah satu fungsi masjid yang tidak dapat dihilangkan adalah fungsi administrator dana infaq. [1]

Sebagian besar dari dana infaq yang dimiliki oleh masjid di Indonesia masih banyak yang menganggur dan bertambah banyak, karena belum dimanfaatkan secara optimal. Padahal, dana infaq yang optimal adalah dana yang segera dialokasikan untuk kemaslahatan umat. Berdasarkan penelitian yang telah dilakukan oleh Dr. Muhammad Akhyar Adnan, MBA., Ak., CA selaku Kepala Pusat Studi Pengembangan Ekonomi Islam dan Filantropi (PuSPEIFi) UMY, pada tahun 2012 masih banyak ditemukan dana masjid yang menganggur dan masih belum digunakan secara optimal.

Fenomena ini juga terjadi pada Masjid Ibrahimdi Kadipiro Yogyakarta. Takmir saat ini belum optimal dalam mengelola dana infaq masjid secara tepat. Menurut informasi bendahara Masjid Ibrahim, pada bulan Februari tahun 2020 dan sebelumnya rata-rata saldo dana infaq Masjid Ibrahimmencapai Rp.45.000.000 hingga Rp. 50.000.000. Selama itu dana infaq hanya dipergunakan untuk keperluan pembiayaan masjid dan fasilitasnya saja, dan hanya sebagian kecil yang dialokasikan untuk membiayai sosial. Takmir Masjid Ibrahimbelum optimal dalam melakukan inovasi penggunaan dana infaq masjid yang merupakan amanah dari para jamaah untuk dimanfaatkan bagi umat.

Pada masa pandemi Covid-19 ini masyarakat sangat membutuhkan bantuan penanganan pandemi, baik bantuan secara ekonomi maupun bantuan sosial lainnya. Masjid seharusnya dapat berperan dalam membantu menangani pandemi Covid-19 bagi masyarakat sekitarnya. Takmir masjid memiliki peran sentral dalam pengelolaan dana infaq yang diberikan masyarakat melalui masjid. Takmir masjid perlu mengoptimalkan fungsi masjid sebagai tempat ibadah, fungsi sosial, fungsi politik, fungsi pendidikan, fungsi ekonomi lewat pengelolaan dana infaq [1]. Oleh karena itu takmir perlu mengidentifikasi kembali kebutuhan masyarakat yang berkaitan dengan fungsi-fungsi tersebut. Berdasarkan fenomena 
tersebut, perlu dilakukan pendampingan untuk meningkatkan kapasitas takmir Masjid Ibrahimdalam pengelolaan dana infaq pada masa pandemi Covid-19.

\section{Gambaran IPTEK}

Program Kemitraan Masyarakat (PKM) menerapkan ilmu manajemen kepada segenap anggota takmir Masjid Ibrahim. Ilmu manajemen diawali dengan perencanaan, pengorganisasian, pengkoordinasian dan pengawasan/pengontrolan. Takmir Masjid Ibrahim perlu melakukan perencanaan dalam pengelolaan dana infaq masjid. Takmir bisa membuat perencanaan dalam menyusun sumber dan penggunaan dana infaq.

Perencanaan sumber dana ini membutuhkan informasi besarnya dana yang dapat diperoleh dari infaq jama'ah berbasis pengalaman yang telah lalu. Dari sumber dana tersebut, maka takmir bisa merencanakan penggunaan dana infaq masjid secara optimal untu membiayai segala kebutuhan rutin masjid maupun kebutuhan dana lain yang selama ini belum teralokasikan, seperti kebutuhan sosial kemayarakatan, membantu jamaah yang membutuhkan. Dalam hal pengorganisasian, takmir perlu mengevaluasi struktur organisasi takmir masjid serta membuat deskripsi tugas kepada masing-masing angota. Pengoordinasian mencakup koordinasi pelaksanaan dari rencana yang sudah dibuat, dan pengawasan merupakan evaluasi pelaksanaan saat ini dan mengawasi apakah rencana sudah terlaksana dengan optimal.

\section{Metoda Pelaksanaan}

Penanganan permasalahan permasalahan pengelolaan dana infaq yang dialami oleh takmir Masjid Ibrahim membutuhkan peran dari berbagai pihak, khususnya peran takmir masjid dan masyarakat. Program Kemitraan Masyarakat ini diharapkan dapat memberikan model pengelolaan dana infaq masjid di Desa Ngestiharjo Kasihan Bantul Yogyakarta, dengan dipelopori oleh Masjid Ibrahim yang berlokasi di Dusun Kadipiro, Desa Ngestiharjo.

Program Kemitraan Masyarakat dilakukan dengan berbagai pendekatan, yaitu:

a. Berbasis kelompok, di mana seluruh tahan dan jenis kegiatan dilakukan oleh segenap ketua dan anggota takmir Masjid Ibrahim mulai dari perencanaan, pengorganisasian, pengoordinasian hingga pengontrolan.

b. Komprehensif, program PKM ini mengintervensi seluruh aspek untuk melakukan pelatihan dan pendampingan bagi kelompok takmir Masjid Ibrahim dalam meningkatkan keahlian, keterampilan, dan pengetahuan (pengelolaan dana infaq masjid Ibrahim).

\section{Hasil Pelaksanaan}

Berikut ini adalah hasil pelaksanaan dari pendampingan pada Program Pengabdian Masyarakat Skema Program Kemitraan Masyarakat (PKM) pada takmir masjid Ibrahim.

\section{Brainstorming}

Brainstorming mengenai permasalahan pengelolaan dana infaq di Masjid Ibrahim yang diikuti oleh semua anggota pengurus takmir masjid dipandu oleh pendamping. Pada bulan Maret 2020 diadakan sosialisasi Pengabdian Masyarakat Skema Program Kemitraan Masyarakat (PKM) Universitas Muhammadiyah Yogyakarta, yang dihadiri oleh ketua dan segenap pengurus takmir Masjid Ibrahim. Sosialisasi Pengabdian Masyarakat Skema Program Kemitraan Masyarakat (PKM) Universitas Muhammadiyah Yogyakarta tersebut menjelaskan mengenai:

a. Latar belakang diadakannya kegiatan

b. Rencana kegiatan

c. Tahapan benchmarking. Benchmarking pada masjid merupakan suatu proses belajar dengan melakukan kegiatan mengukur dan membandingkan setiap bagian yang dinyatakan penting oleh masjid, dengan masjid lain yang terbaik [2].

Dokumentasi sosialisasi dapat dilihat pada gambar 1. 


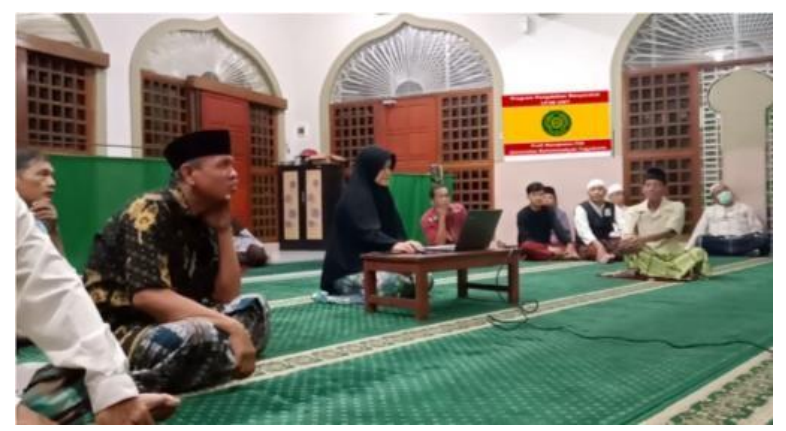

Gambar 1. Sosialisasi Pengabdian Masyarakat Skema Program Kemitraan Masyarakat (PKM) UMY

\section{Penyerahan bantuan printer kepada takmir Masjid Ibrahim}

Berdasarkan proses brainstorming, takmir masjid membutuhkan peralatan berupa printer yang dilengkapi dengan scanner dan fotokopi. Printer ini berfungsi untuk membuat undangan rapat dan kegiatan lainnya di masjid Ibrahim, dan juga dapat dimanfaatkan masyarakat terutama pelajar yang berada di lingkungan Masjid Ibrahimyang membutuhkan pencetakan dokumen tugas sekolah dan lainlain. Penyerahan printer yang dilengkapi scanner dan fotokopi dapat dilihat pada gambar 2.

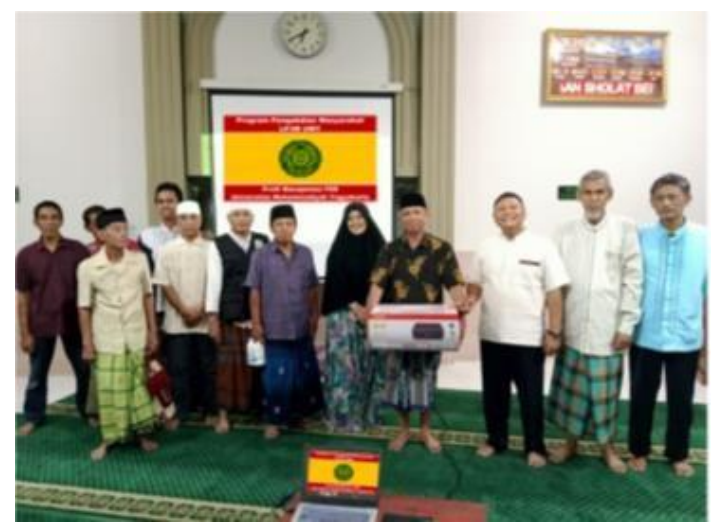

Gambar 2. Penyerahan Printer yang dilengkapi dengan Scanner dan fotokopi

Pada Pengabdian Masyarakat Skema Program Kemitraan Masyarakat (PKM) UMY

\section{Penyerahan bantuan hand sanitizer}

Pada bulan Maret, Masjid Ibrahim masih menyelenggarakan kegiatan seperti biasanya, meskipun sudah mulai tersebar gejala pandemi COVID-19. Melihat situasi tersebut, maka Pengabdian Masyarakat Skema Program Kemitraan Masyarakat (PKM) Universitas Muhammadiyah Yogyakarta memberikan bantuan berupa hand sanitizer sebagaimana dapat dilihat pada gambar berikut:

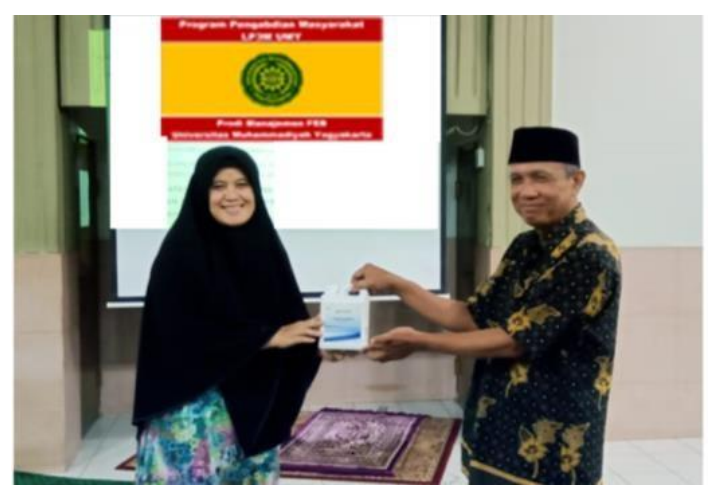

Gambar 3. Penyerahan Bantuan Sanitizer 1 liter

Pengabdian Masyarakat Skema Program Kemitraan Masyarakat (PKM) UMY 


\section{Perbaikan Struktur Organisasi Takmir Masjid Ibrahim}

Struktur organisasi takmir Masjid Ibrahim selama ini masih memasukkan anggota yang sudah meninggal. Tugas yang seharusnya dilaksanakan oleh pengurus menjadi tidak berjalan dengan baik. Oleh karena itu pada program PKM ini juga dilakukan penggantian anggota takmir yang sudah meninggal, sekaligus pengesahan susunan anggota takmir yang baru oleh bapak Taufiqurrahman, S.E., M.Si, ketua takmir Masjid Ibrahim.

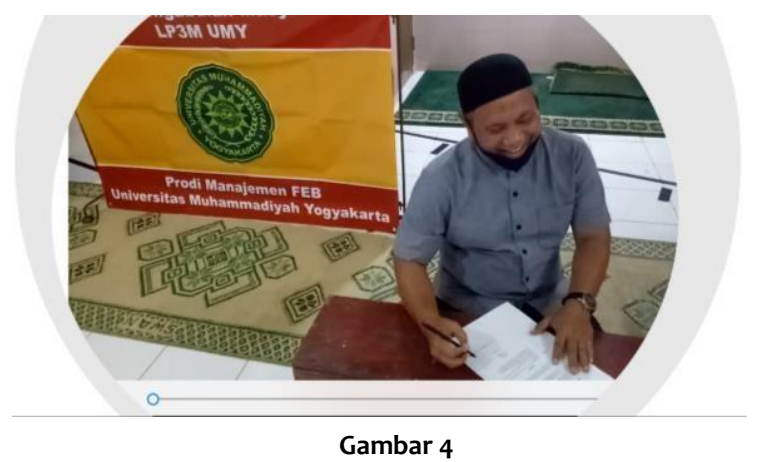

Pengesahan Perubuhan Struktur Organisasi Takmir oleh Ketua Takmir Masjid Ibrahim

\section{Studi Banding Pengelolaan Dana Infaq pada Masjid Al Ikhlas}

Studi banding pengelolaan dana infaq masjid pada awalnya akan dilakukan dengan mengunjungi masjid lain yang memiliki pengelolaan dana infaq yang lebih baik. Kondisi pandemi Covid-19 membuat situasi tidak memungkinkan untuk berkunjung ke tempat lain. Sebagai solusinya, studi banding dalam program PKM ini dilakukan dengan menghadirkan ketua takmir masjid Al Ikhlas Soragan, yaitu bapak Arif untuk menjelaskan pengelolaan dana infaq di masjid Al Ikhlas, sekaligus upaya memakmurkan masjid yang telah dilakukan.

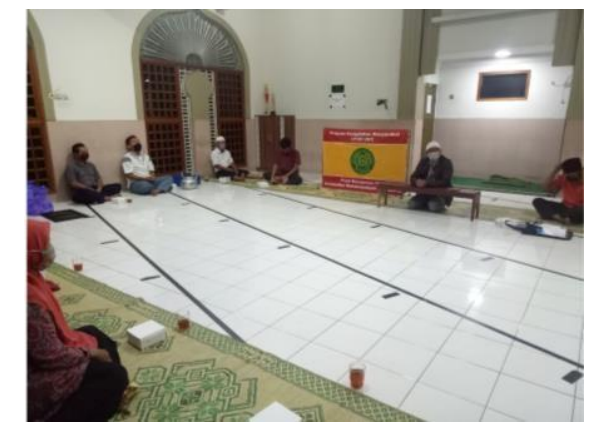

Gambar 5

Studi Banding Pengelolaan Dana Infaq pada Masjid Al Ikhlas

\section{Pemanfaatan dana infaq masjid Ibrahim}

Mulai bulan April, Masjid Ibrahim melakukan lockdown sebagaimana himbauan dari pemerintah desa maupun pemerintah kabupaten dan provinsi. Kegiatan jum'atan, pengajian-pengajian, dan kegiatan lain di Masjid Ibrahim dihentikan sementara. Kegiatan salat jama'ah 5 waktu diadakan, namun dibatasi pada penduduk sekitar Masjid Ibrahim. Shaf salat pun juga dibuat berjarak untuk mendapatkan social distancing demi mencegah penularan wabah COVID-19. Tahap Pada bulan Juni salat Jum'at pelan- pelan diselenggarakan dengan jumlah jamaah yang dibatasi pada penduduk sekitar Masjid Ibrahim. Sejak bulan April hingga bulan Juli 2020, jalan menuju masjid Ibrahmim masih diportal untuk mencegah pendatang dari luar daerah memasuki kampung dan Masjid Ibrahim. Situasi pembatasan jama'ah dan penghentian salat jum'at selama beberapa waktu berdampak pada pemasukan dana infaq Masjid Ibrahim.

Menurut laporan bendahara masjid, Saldo awal infaq Masjid Ibrahim pada masa sebelum pandemi 
Covid-19 totalnya sebesar Rp. 45.000 .000 hingga 50.000.000. Infaq masjid pada situasi normal setiap minggunya bisa mencapai Rp. 1.500.000 hingga Rp. 2.000.000 atau sekitar Rp.7.000.000 hingga Rp.8.000.000 setiap bulannya. Pada masa pandemi COVID-19 ini jumlah infaq turun dratis hingga rata-rata setiap minggunya hanya 600.000 an hanya Rp.2.423.700 setiap bulannya.

Contoh laporan dana pemasukan dari infaq di Masid Ibrahim yang ditampilkan di papan tulis masjid sebelum pandemi COVID-19 yang dituliskan di papan masjid dapat dilihat pada gambar 4.

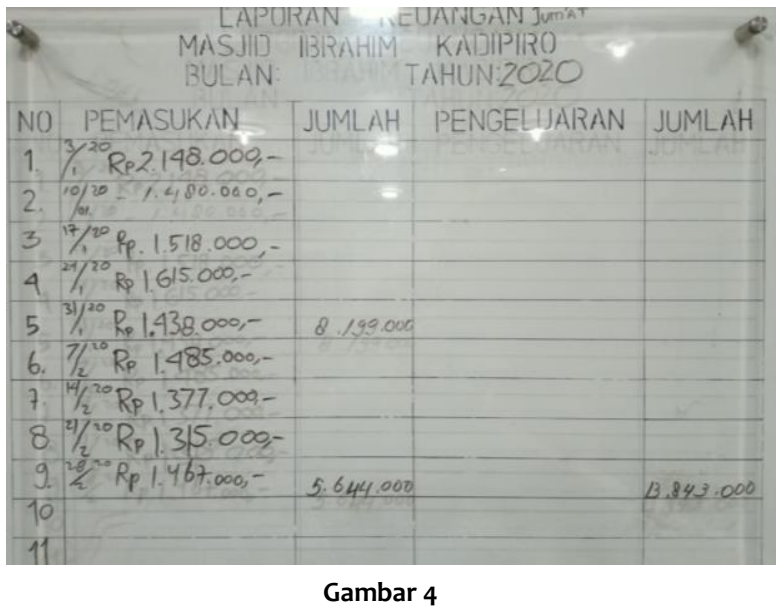

Laporan Pemasukan Dana Infaq di Papan Tulis Masjid Ibrahim

Dalam masa pandemi COVID-19, laporan keuangan tidak ditampilkan di papan pengumuman, karena masjid di lockdown beberapa bulan, dan jama'ah hanya dibatasi penduduk sekitar masjid saja. Adapun laporan pemasukan dan pengeluaran dana infaq semasa Covid pada catatan bendahara masjid adalah sebagai berikut:

\begin{tabular}{|l|r|r|}
\hline \multicolumn{2}{|l|}{ Infak selama Covid 19} \\
\hline 17-Apr & 1 infak & 1.345 .000 \\
\hline Mei s.d 12 Juni & 1 . infak & 4.216 .000 \\
\hline 19 Juni & 1 infak & 600.000 \\
\hline 26 Juni & 1 infak & 1.110 .000 \\
\hline & & 7.271 .000 \\
\hline Pengeluaran & & \\
\hline laudry rukuh & 48.500 & 7.222 .500 \\
\hline cuci karpet & 390.000 & 6.832 .500 \\
\hline Desinfektan 10 liter & 1.000 .000 & 5.832500 \\
\hline alat semprot & 750.000 & 5.082500 \\
\hline CCTV & 800.000 & 4.282500 \\
\hline Pemasangam dill & 500.000 & 3.782 .500 \\
\hline Oprasional Semprot & 1.600 .000 & 2.182 .500 \\
\hline
\end{tabular}

Gambar 5

Laporan Pemasukan dan Pengeluaran Dana Infaq Masjid Ibrahim Selama Pandemi COVID-19

Berdasarkan laporan infaq selama pandemi COVID-19 dapat dilihat bahwa rata-rata pemasukan dalam 3 bulan sekitar Rp.2.423.700 setiap bulannya. Pemanfaatan dana infaq selama masa pandemi COVID- 19 menunjukkan pengeluaran yang cukup besar. Artinya dana infaq dimanfaatkan untuk kepentingan masjid dan kepentingan masyarakat. Dana infaq yang digunakan untuk kepentingan masjid, seperti laundry mukena Rp. 48.500, cuci karpet untuk salat Rp.390.000, disinfektan 10 liter 
Rp.1000.000, alat semprot disinfektan Rp.750.000, CCTV Rp.800.000 dan pemasangannya Rp.500.000, operasional semprot Rp. 1.600.000. Secara terperinci, pemanfaatan dana infaq Masjid Ibrahim selama pelaksanaan Pengabdian Masyarakat Skema Program Kemitraan Masyarakat (PKM) Universitas Muhammadiyah Yogyakarta tersebut adalah sebagai berikut.

a. Pencucian Karpet

Pencucian karpet yang dilakukan oleh takmir Masjid Ibrahim dimaksudkan untuk menjaga kebersihan karpet sebelum karpet tersebut digulung dan disimpan. Hal ini dikarenakan selama masa pandemi COVID jama'ah diminta untuk membawa sajadah sendiri dari rumah masing-masing untuk mencegah penularan COVID.

b. Pembelian dan penyemprotan disinfektan

Pembelian disinfektan cukup banyak, karena digunakan untuk penyediaan disinfektan di depan pintu masjid, dan juga untuk penyeprotan secara berkala pada rumah-rumah penduduk sekitar Masjid Ibrahim. Alat penyemprot juga dibeli untuk kepentingan tersebut. Selama pandemi COVID-19, takmir masjid memanfaatkan dana infaq untuk melakukan penyemprotan seminggu sekali ke rumah warga sekitar Masjid Ibrahim, dengan menyediakan dana untuk biaya disinfektan, pembelian peralatan, maupun operasionalisasi bagi petugas yang menlakukan penyemprotan ke rumah-rumah penduduk. Pemasangan CCTV juga dilakukan oleh takmir Masjid Ibrahim, karena beberapa kali di Masjid Ibrahim terjadi pencurian uang infaq oleh pencuri. CCTV dipasang di dalam masjid pada berbagai sisi dan bagian luar masjid Ibrahim.

Penyemprotan disinfektan ke rumah-rumah penduduk sekitar masjid dilakukan secara periodik seminggu sekali menggunakan dana infaq masjid. Rumah penduduk yang disemprot disinfektan adalah pada rumah penduduk muslim maupun nonmuslim. Dana infaq dimanfaatkan untuk kemaslahatan umat. Pelaksana Program Kemitraan Masyarakat Universitas Muhammadiyah Yogyakarta memfasilitasi peminjaman mobil yang digunakan untuk melakukan penyemprotan disinfektan ke rumah-rumah penduduk. Gambar 5 menunjukkan kegiatan penyemprotan disinfektan ke rumah-rumah penduduk.

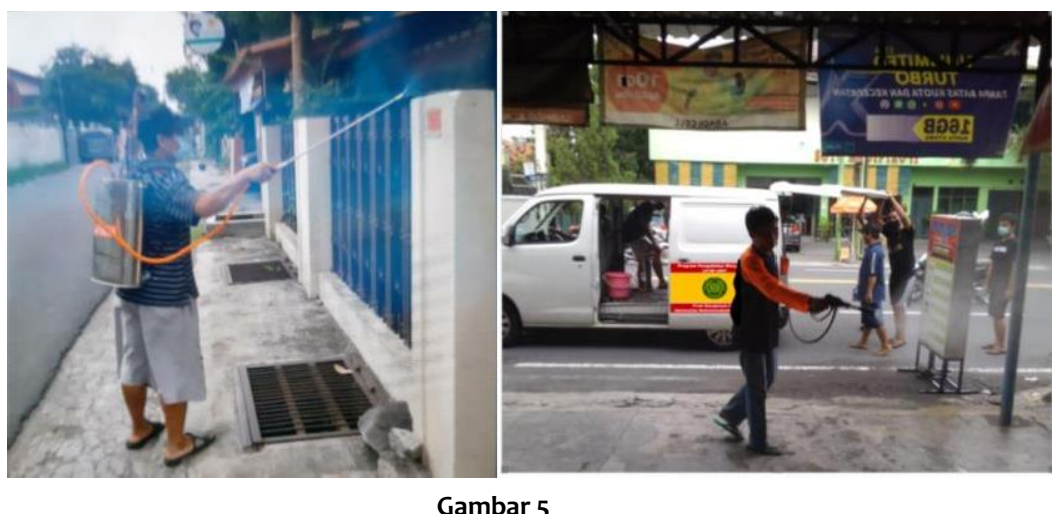

Kegiatan Penyemprotan Disinfektan ke Rumah-Rumah Penduduk Didanai oleh Takmir Masjid

Ibrahim

c. Pembuatan dan pemasangan pintu lockdown menuju masjid Ibrahim

Takmir Masjid Ibrahim juga membiayai pembuatan pintu besi untuk menjaga Masjid Ibrahim dan lingkungannya dari penyebaran Covid-19. Jama'ah yang diperbolehkan untuk mengikuti salat dan kegiatan Masjid Ibrahim sementara dibatasi hanya penduduk sekitar masjid saja, dan masih membatasi kehadiran pengunjung dari luar daerah Kadipiro. Gambar 6 menunjukkan palang pintu Lockdown menuju masjid Ibrahim. 


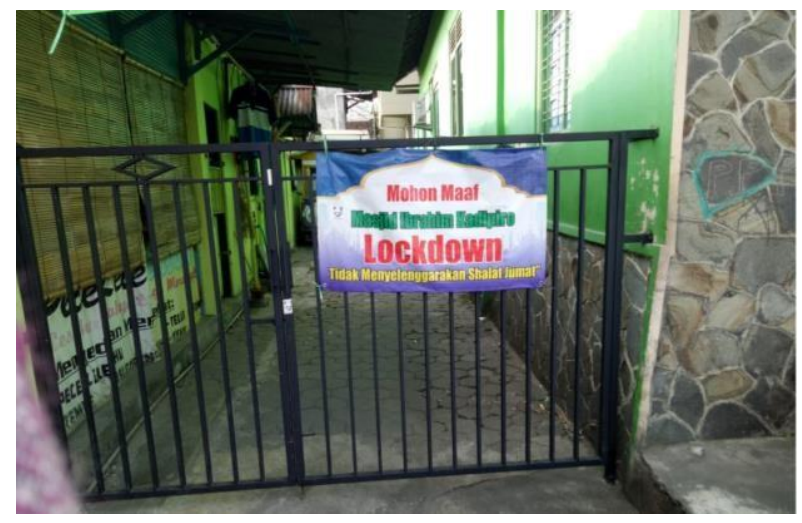

Gambar 6

Palang Pintu Lockdown Masjid Ibrahim yang Didanai dengan Dana Infaq Masjid Ibrahim

d. Pembagian sembako dari dana infaq masjid

Jamaah masjid di wilayah Kadipiro (JAMASKA) memiliki lembaga amal zakat infaq Kadipiro yang dikenal dengan LAZISKA. Masjid Ibrahim adalah salah satu masjid yang menjadi anggota JAMASKA. Pada masa pandemi COVID ini, Masjid Ibrahim juga menghimpun dana dari masyarakat sekitar Masjid Ibrahimdan menyerahkan sebagian dana infaqnya untuk dikelola oleh LAZISKA untuk dibelikan sembako guna dibagikan kepada masyarakat miskin wilayah Kadipiro. Dokumentasi saat pembagian sembako oleh LAZISKA dapat dilihat pada gambar 7.
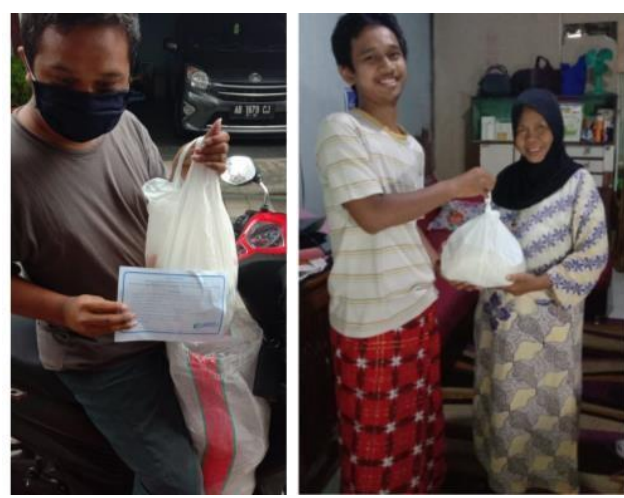

Gambar 7

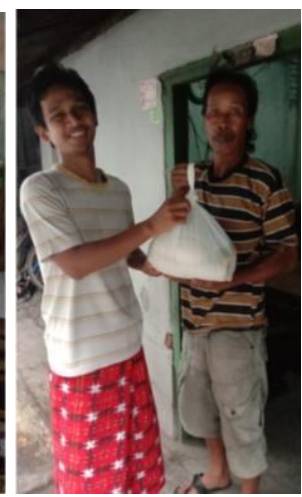

Pembagian Sembako oleh LAZISKA Bekerja Sama dengan Masjid Ibrahim

Pada akhir program pengabdian pada masyarakat ini infaq Masjid Ibrahim telah dikelola dengan baik. Pada awalnya infaq yang tersimpan sebesar Rp. 45.000.000 hingga Rp.50.000.000. Setelah dikelola dengan baik, infaq masjid pada akhir program PKM ini menjadi tinggal Rp. 10.000.000, karena sudah dimanfaatkan dengan baik untuk kemaslahatan umat.

\section{Simpulan}

Dana infaq masjid jika dikelola dengan baik akan bermanfaat bagi kemaslahatan umat, sebagaimana yang telah dilakukan oleh takmir Masjid Ibrahim dalam masa program PKM ini. Dana infaq masjid telah digunakan untuk melengkapi fasilitas fisik masjid, seperti AC, LCD, mimbar, jam digital dan sebagainya. Namun demikian, hal yang lebih penting lagi dalam pengelolaan dana infaq adalah untuk kemaslahatan umat, seperti mendanai bea siswa, membagikan sembako kepada warga yang kekurangan, memberi bantuan kepada warga yang sakit, penyemprotan disinfektan ke rumahrumah penduduk terutama pada masa pandemi covid-19 ini, dan masih banyak lagi. Dana infaq yang optimal adalah jika dimanfaatkan dengan baik dan segera. 


\section{References}

Yudho Anggoro S 2018 The Analysis Of Infaq Fund Administration Masjid Jogokariyan Mantrijeron Yogyakarta In Islamic Perspective JEBIS 478

Munawaroh M 2015 Manajemen Operasi Strategi Untuk Mencapai Keunggulan Kompetitif vol 3 (LP3M UMY) 